\title{
COMMENTARY
}

\section{How much fluid resuscitation is optimal in septic shock?}

\author{
James A Russell* \\ See related research by Smith and Perner, http://ccforum.com/content/16/3/R76
}

\begin{abstract}
Smith and Perner report an observational cohort study of 164 patients with septic shock. For patients still alive on day 3 , higher compared with lower fluid volume resuscitation was associated with lower 90-day mortality. This association of a relationship between fluid intake and decreased mortality aligns with the randomized controlled trial of early goal-directed therapy and later observational studies. I suggest careful individualization of fluid resuscitation to achieve adequate mean arterial pressure (about 60 to $70 \mathrm{mmHg}$ ) and normalization of arterial lactate levels in septic shock.

Trial registration: ISRCTN94845869
\end{abstract}

Despite decades of use, how much fluid is optimal during resuscitation of patients who have septic shock remains uncertain. Excessive fluid increases intravascular pressure, and with increased permeability of sepsis this increases fluid accumulation and organ dysfunction. Conversely, inadequate fluid resuscitation causes tissue hypoxia secondary to inadequate global oxygen delivery. Furthermore, excessive doses of vasopressors (consequent to inadequate fluid resuscitation) constrict the microvasculature, leading to tissue hypoxia.

Smith and Perner report an observational cohort study of 164 patients with septic shock [1]. They recorded fluid intake and correlated fluid intake to clinical outcomes. For patients still alive on day 3, higher compared with lower fluid volume resuscitation (10.9 l vs. $4.3 \mathrm{l}$ ) was associated with significantly lower 90 -day mortality $(40 \%$ vs. $62 \%, P=0.03$ ). This association of a relationship between fluid intake and decreased mortality aligns with the randomized controlled trial (RCT) of early goal-directed

*Correspondence: Jim.Russell@hli.ubc.ca

Critical Care Medicine, St. Paul's Hospital, 1081 Burrard Street, Vancouver, BC, Canada, V6Z 1Y6 therapy (EGDT) by Rivers and colleagues [2]. In particular, Rivers and colleagues found that fluid and vasopressor resuscitation titrated to increase and maintain central venous oxygen saturation above $70 \%$ in patients who had septic shock was associated with increased fluid intake in the emergency department (first 6 hours) and with significantly decreased mortality [2].

Accordingly, sepsis guidelines [3] and Russell [4] have recommended EGDT fluid management for the first 6 hours of septic shock. Rivers and colleagues' RCT is being repeated in three large multicenter RCTs in the UK, the USA and Australia, and the results of those RCTs are awaited with considerable interest around the globe. Many case-control studies (often before and after implementation of sepsis guidelines, one component of which is use of Rivers and colleagues' protocol) suggest that EGDT bundles improve outcomes [5-16], including a meta-analysis [9] (Table 1).

Based on observational studies that found a positive association of early clearance of arterial lactate and better clinical outcomes [17], Jones and colleagues performed a $\mathrm{RCT}$ to compare titration of emergency resuscitation of patients who have septic shock with central venous oxygen saturation and with serial decrease of arterial lactate (which is less invasive). They found that arterial lactate was not inferior to central venous oxygen saturation-guided resuscitation [18]. As a result, it is reasonable to target normalization of arterial lactate to guide fluid intake and vasopressor use in patients with septic shock.

The strengths of Smith and Perner's study were that it was an observational cohort from six hospitals with no exclusions and that they carefully recorded volumes and types of fluids administered over the first 3 days of septic shock [1]. The study thus scores high on generalizability.

Several aspects of the study require consideration, however. First, their study was small, and so the clinical community would like to see other larger cohorts used to address this problem. Second, nutritional fluids were not included in the calculations of fluid intake and fluid balance. The total of all fluids given should be used in assessing effects of fluid administration. Indeed, Smith and Perner found that their higher volume group received 
Table 1. Relevant cohort studies of high versus low fluid volume in sepsis and septic shock

\begin{tabular}{|c|c|c|c|c|}
\hline Study & $\begin{array}{c}\text { Clinical } \\
\text { condition studied }\end{array}$ & $\begin{array}{c}\text { Randomized, } \\
\text { controlled } \\
\text { interventions }\end{array}$ & $\begin{array}{l}\text { High fluid } \\
\text { group mortality }\end{array}$ & $\begin{array}{c}\text { Low fluid group } \\
\text { mortality ( } P \text { value for } \\
\text { high vs. low fluid comparison) }\end{array}$ \\
\hline \multicolumn{5}{|l|}{ Randomized controlled trials } \\
\hline Rivers and colleagues [2] & Severe sepsis and septic shock & EGDT vs. usual care & $30.5 \%{ }^{\mathrm{a}}(\mathrm{EGDT})$ & $46.5 \%$ (usual care; $P=0.009$ ) \\
\hline \multicolumn{5}{|l|}{ Observational cohort studies } \\
\hline Smith and Perner [1] & Septic shock & NA & $24 \%$ & $65 \%^{\mathrm{b}}(P<0.001)$ \\
\hline Carlsen and Perner [15] & Septic shock & NA & $38 \%$ & $29 \%(P=0.36)$ \\
\hline McIntyre and colleagues [16] & Septic shock & NA & $45 \%$ & $44 \%$ \\
\hline Vincent and colleagues [11] & Sepsis & NA & & Odds ratio 1.1 per liter increase $\mathrm{e}^{\mathrm{b}}$ \\
\hline Gao and colleagues [8] & Sepsis & NA & $29 \%$ & $55 \%(P=0.045)^{c}$ \\
\hline Jones and colleagues [10] & & NA & $18 \%$ & $27 \%(95 \% \mathrm{Cl}=+5 \% \text { to }-21 \%)^{d}$ \\
\hline Nguyen and colleagues [14] & Sepsis & NA & $26 \%$ & $39 \% \mathrm{e}^{\mathrm{C}}$ \\
\hline
\end{tabular}

$\mathrm{Cl}$, confidence interval; EGDT, early goal-directed therapy; NA, not applicable. a Statistically significant in favor of high fluid group compared with low fluid group

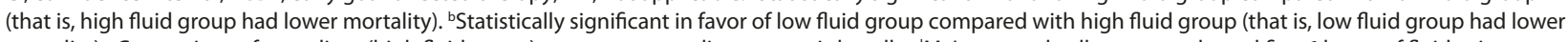
mortality). 'Comparison of compliant (high fluid group) versus noncompliant to sepsis bundle. ${ }^{\mathrm{d}} \mathrm{Mclntyre}$ and colleagues evaluated first 6 hours of fluids given. eCompletion of EGDT within 6 hours (high fluid group) or not.

significantly less volume of nutrition compared with the lower volume group (2.9 l vs. 3.4 l) [1]; the addition of nutritional fluids could alter the results and their interpretation.

One should not confuse early resuscitation fluid intake with studies of overall later fluid balance, which have sometimes found association of more positive fluid balance with increased mortality $[19,20]$. However, the cause-effect relationship is not resolved in such observational studies; more positive fluid balance could alter outcomes or could simply be a marker of increased endothelial injury and third-spacing of fluids in sicker patients (who have increased mortality because of increased endothelial injury and not necessarily due to more positive fluid balance).

In summary, Smith and Perner report a small observational cohort [1] that must be placed in context of prior studies. Rivers and colleagues' RCT of EGDT and other observational studies show that more positive fluid intake is associated with decreased mortality. The ongoing RCTs of EGDT in Australia, the USA and the UK will provide clearer evidence about how much fluid resuscitation is optimal in septic shock. Until then, I suggest careful individualization of fluid resuscitation to achieve adequate mean arterial pressure (about 60 to $70 \mathrm{mmHg}$ ) and normalization of arterial lactate levels in septic shock.

\section{Abbreviations}

EGDT, early goal-directed therapy; $R C T$, randomized controlled trial.

\section{Competing interests}

JAR reports holding stock in and is on the board of Sirius Genomics Incorporated, which has submitted patents owned by the University of British Columbia and licensed to Sirius Genomics that are related to the genetics of sepsis and its treatment. The University of British Columbia has also submitted a patent related to the use of vasopressin in septic shock. JAR is an inventor on these patents. JAR also reports receiving consulting fees from Ferring Pharmaceuticals (which manufactures vasopressin and is developing selepressin), from Astra Zeneca (which is developing anti-TNFa), from BioCritica (which used to sell activated protein C in the USA), from Medlmmune, from Grifols (which sells albumin) and from Sirius Genomics Inc. JAR also reports having received grant support from Sirius Genomics, Ferring Pharmaceuticals, Astra Zeneca and Eli Lilly that is provided to and administered by University of British Columbia. JAR has received speaking honoraria from Pfizer and Eli Lilly.

\section{Acknowledgements}

Support for the Vasopressin and Septic Shock Trial was received from the Canadian Institutes of Health Research (grant number MCT 44152)

Published: 8 August 2012

\section{References}

1. Smith SH, Perner A: Higher vs. lower fluid volume for septic shock: clinical characteristics and outcome in unselected patients in a prospective, multicenter cohort. Crit Care 2012, 16:R76.

2. Rivers E, Nguyen B, Havstad S, Ressler J, Muzzin A, Knoblich B, Peterson E, Tomlanovich M: Early goal-directed therapy in the treatment of severe sepsis and septic shock. N Engl J Med 2001, 345:1368-1377.

3. Dellinger RP, Levy MM, Carlet JM, Bion J, Parker MM, Jaeschke R, Reinhart K, Angus DC, Brun-Buisson C, Beale R, Calandra T, Dhainaut JF, Gerlach H, Harvey M, Marini JJ, Marshall J, Ranieri M, Ramsay G, Sevransky J, Thompson BT, Townsend S, Vender JS, Zimmerman JL, Vincent JL: Surviving Sepsis Campaign: international guidelines for management of severe sepsis and septic shock: 2008. Crit Care Med 2008, 36:296-327.

4. Russell JA: Management of sepsis. N Engl J Med 2006, 355:1699-1713.

5. de Sousa AG JC, Santos GPD: The impact of each action in the Surviving Sepsis campaign measures on hospital mortality of patients with severe sepsis/septic shock. Einstein 2008, 6:323-327.

6. Ferrer R, Artigas A, Levy MM, Blanco J, González-Díaz G, Garnacho-Montero J, Ibáñez J, Palencia E, Quintana M, de la Torre-Prados MV: Improvement in process of care and outcome after a multicenter severe sepsis educational program in Spain. JAMA 2008, 299:2294-2303.

7. Ferrer R, Artigas A, Suarez D, Palencia E, Levy MM, Arenzana A, Pérez XL, Sirvent JM: Effectiveness of treatments for severe sepsis: a prospective, multicenter, observational study. Am J Respir Crit Care Med 2009, 180:861-866

8. Gao F, Melody T, Daniels DF, Giles S, Fox S: The impact of compliance with 6-hour and 24-hour sepsis bundles on hospital mortality in patients with 
severe sepsis: a prospective observational study. Crit Care 2005, 9:R764-R770.

9. Jones AE, Brown MD, Trzeciak S, Shapiro NI, Garrett JS, Heffner AC, Kline JA The effect of a quantitative resuscitation strategy on mortality in patients with sepsis: a meta-analysis. Crit Care Med 2008, 36:2734-2739.

10. Jones AE, Focht A, Horton JM, Kline JA: Prospective external validation of the clinical effectiveness of an emergency department-based early goaldirected therapy protocol for severe sepsis and septic shock. Chest 2007, 132:425-432.

11. Vincent JL, Sakr Y, Sprung CL, Ranieri VM, Reinhart K, Gerlach H, Moreno R, Carlet J, Le Gall JR, Payen D: Sepsis in European intensive care units: results of the SOAP study. Crit Care Med 2006, 34:344-353.

12. Levy MM, Dellinger RP, Townsend SR, Linde-Zwirble WT, Marshall JC, Bion J, Schorr C, Artigas A, Ramsay G, Beale R, Parker MM, Gerlach H, Reinhart K, Silva E, Harvey M, Regan S, Angus DC: The Surviving Sepsis Campaign: results of an international guideline-based performance improvement program targeting severe sepsis. Crit Care Med 2010, 38:367-374.

13. Lin SM, Huang CD, Lin HC, Liu CY, Wang CH, Kuo HP: A modified goaldirected protocol improves clinical outcomes in intensive care unit patients with septic shock: a randomized controlled trial. Shock 2006 26:551-557.

14. Nguyen HB, Corbett SW, Steele R, Banta J, Clark RT, Hayes SR, Edwards J, Cho TW, Wittlake WA: Implementation of a bundle of quality indicators for the early management of severe sepsis and septic shock is associated with decreased mortality. Crit Care Med 2007, 35:1105-1112.
15. Carlsen S, Perner A: Initial fluid resuscitation of patients with septic shock in the intensive care unit. Acta Anaesthesio/ Scand 2011, 55:394-400.

16. McIntyre LA, Fergusson D, Cook DJ, Nair RC, Bell D, Dhingra V, Hutton B, Magder S, Hébert PC: Resuscitating patients with early severe sepsis: a Canadian multicentre observational study. Can J Anaesth 2007, 54:790-798.

17. Nguyen HB, Rivers EP, Knoblich BP, Jacobsen G, Muzzin A, Ressler JA, Tomlanovich MC: Early lactate clearance is associated with improved outcome in severe sepsis and septic shock. Crit Care Med 2004, 32:1637-1642.

18. Jones AE, Shapiro NI, Trzeciak S, Arnold RC, Claremont HA, Kline JA: Lactate clearance vs central venous oxygen saturation as goals of early sepsis therapy: a randomized clinical trial. JAMA 2010, 303:739-746.

19. Boyd JH, Forbes J, Nakada TA, Walley KR, Russell JA: Fluid resuscitation in septic shock: a positive fluid balance and elevated central venous pressure are associated with increased mortality. Crit Care Med 2011, 39:259-265.

20. Murphy CV, Schramm GE, Doherty JA, Reichley RM, Gajic O, Afessa B, Micek $\mathrm{ST}$, Kollef $\mathrm{MH}$ : The importance of fluid management in acute lung injury secondary to septic shock. Chest 2009, 136:102-109.

doi:10.1186/cc11393

Cite this article as: Russell JA: How much fluid resuscitation is optimal in septic shock? Critical Care 2012, 16:146. 